\title{
PENGUATAN KAPASITAS BUDAYA ANDEB ASHOR DAN PATRONISASI MASYARAKAT MADURA
}

\author{
Laili Amalia', Hayat ${ }^{2}$ \\ ${ }^{1}$ Universitas Madura \\ email: lailiunira@gmail.com \\ 2Universitas Islam Malang \\ email: hayat@unisma.ac.id
}

\begin{abstract}
ABSTRAK
Kecepatan teknologi dan informasi serta globalisasi yang semakin instan memberikan konskuensi nyata dalam kehidupan masyarakat kini. Rasa individualisme terus bergerak menuju struktur sosial masyarakat indonesia yang disertai oleh jarak yang didekatkan oleh teknologi tetapi dijauhkan oleh rasa ukhuwah islamiyah yang semakin terkikis. Patronisasi sudah bergeser, dari panutan terhadap orang-orang yang berilmu, sholeh dan dekat dengan Tuhannya, beralih kepada kekuatan teknologi sebagai alat komunikasi dan menyelesaikan persoalan hidup. Tak terkecuali, masyarakat Madura yang dikenal sebagai masyarakat santri, meneguhkan nilai andeb ashor dalam kehidupan keluarga maupun sosial kemasyarakatan. penuh ketawadduan terhadap nilai-nilai patronisasi kepada kiai, ulama dan orang alim, menjunjung tinggi nilai-nilai sosial kemasyarakat, kegotongroyongan, musyawarah mufakat sebagai pengambilan keputusan dalam struktur sosial masyarakat Madura, serta kehidupannya yang memegang teguh pada prinsip-prinsip kebersamaan dan kemandirian sosial
\end{abstract}

Kata kunci: penguatan kapasitas, budaya, andeb ashor, patron, madura

\section{PENDAHULUAN}

Masyarakat Madura terkenal sebagai masyarakat santri. Penuh ketakdiman dan penghormatan melalui andeb ashor yang dibangun oleh struktur sosial sejak lama. Struktur sosial masyarakat Madura mempunyai nilai falsafah tinggi dalam kehidupan bermasyarakat, berbangsa dan bernegara. Nilai-nilai luhur yang ditampakkan adalah menjadikan patron sebagai penguatan kapasitas dalam pembangunan manusia Madura.

Seorang kiai sangat dihormati dalam struktur sosial kemasyarakatan. Tunduk dan patuh akan fatwa segala perintahnya. Hal itu menandakan bahwa mempunyai konsep moral dan perilaku yang dijunjung sebagai bagian dari penguatan kapasitas sumber daya manusia Madura.

Namun demikian, dalam kehidupan modern kini, budaya-budaya luhur mengalami degradasi cukup tinggi akhir-akhir ini. Banyak faktor yang mempengaruhinya, antara lain teknologi yang semakin dinamis, hedonisme masyarakat tak terelakkan dalam berbagai aspek kehidupan, individualistik mulai tumbuh seiring dengan perkembangan dan pertumbuhan ekonomi yang semakin mengalami kapitalistik, serta demoralisasi pergaulan semakin intens menyerang generasi masyarakat Madura kini.

Modernisasi menjadi cikal bakal masuknya globalisasi masyarakat madura. Industrisliasasi sudah sengat aktif dalam kehidupan masyarakat madura kini. Masyarakat 
dihadapkan kepada sebuah dilema, dimana menjadi keterpaksaan menerimma nilai-nilai material dan sekular secara total sebagai upaya untuk memperoleh perasaan konsonan baru dengan menolak tradisi yang sudah ada, tetapi menyakitkan jika tidak berkembang. (Latif, 2016:175).

Tentu, ini menjadi tantangan bagi kita semua sebagai masyarakat Madura untuk mengembalikan pilar-pilar budaya yang ditancapkan oleh para sesepuh Madura sebagai pijakan menapaki kehidupan yang semakin kompleks, terutama peran generasi muda yang menjadi titik sentral pembangunan masyarakat Madura ke depan.

\section{METODE}

Metode penulisan artikel ini menggunakan kajian pustaka yang dihimpun berdasarkan data-data atau dokumen-dokumen dari berbagai literatru (buku, jurnal, informasi yang kredibel, hasil penelitian, dll) maupun dari berbagai informasi lain yang dapat dipertanggungjawabkan sebagai bentuk pengayaan dan preferensi dalam tulisan ini. Di samping itu, hasil data-data atau dokumen-dokumen tersebut dikaji ulang dan dianalisis sesuai dengan konteks dan substansi kajiannya untuk menghasilkan analisis yang mendalam. Pisau analisisnya menggunakan studi kasus dengan pendekatan kualitatif untuk memberikan penajaman terhadap pisau analisis yang dibuat, sehingga menghasilkan kajian yang komprehensif dan dinamis dengan mengedepankan prinsip-prinsip keadilan dan keseimbangan.

\section{HASIL DAN PEMBAHASAN}

\section{Revitalisasi Struktur Sosial}

Nilai andeb ashor adalah sebuah sikap yang diajarkan dalam agama islam, yaitu ketawaduan dan rendah hati. Masyarakat madura adalah dominasi dari nilai-nilai yang diajarkan oleh agama islam. Faktanya adalah bahwa seluruh masyarakat madura hampir semuanya memeluk agama islam dengan ketaatannya sebagai jati dirinya. (Wiyata, 2016). Termasuk budaya andeb ashor yang menjadi jati diri masyarakat madura. Ditambahkan oleh Wiyata (2016) bahwa identitas keislamana masyarakat madura sangat penting dalam kehidupan sosialnya, kehidupan masyarakatnya maupun kehidupan dalam berbangsa dan bernegara.

Membangun kembali budaya andeb ashor dan menguatkan nilai patronisasi memberikan implikasi yang baik terhadap struktur sosial masyarakat Madura. Masyarakat Madura kaya akan jati diri dan kapasitasnya dalam pembangunan manusia, yaitu lekatnya budaya dan pekerti yang terus terjaga hingga kini.

Arus globalisasi dan modernisasi memberikan dampak yang sangat siginifikan dalam struktur sosial masyarakat indonesia. Teknologi informasi yang semakin cepat memberikan kenyamanan dan kenikmatan bagi masyarakat modern kini. Kebutuhan serba instan memberikan kemudahan dalam kehidupan sehari-hari, cepat, murah, dan mudah. Bisa dikerjakan secara mandiri tanpa bantuan orang lain, yang penting ada uang sebagai alat tukar dari kenikmatan dan kenyamanan itu.

Nilai andeb ashor dijunjung tinggi sebagai nilai etika yang paling mulia dalam kehdiupan masyarakat Madura. Yang tua menghargai yang muda dan yang muda menghormati yang tua. Nilai itu ditanamkan sebagai bentuk dari penguatan terhadap struktur sosial masyarakat yang beradab dan berkehidupan pada nilai-nilai agama. Begitu juga nilai patronisasi menjadi rujukan bagi masyarakat Madura dalam penyelesaian terhadap persoalan hidup dan kehidupan. 
Padahal penting bahwa struktur sosial masyarakat Madura harus dijaga ketertibannya dalam membangun masyarakat yang lebih sejahtera, adil dan makmur. Globalisasi dan modernisasi menjadi tantangan bagi masyarakat Madura untuk terus menyesuaikan dengan kehidupan yang semakin bias, kapitalis dan individualis. Tidak mudah untuk melawan arus globalisasi yang semakin deras menerjang relung-relung kehidupan generasi muda. Menjadi tantangan untuk terus bergerak maju, berkembang, dan bergerak menuju masyarakat Madura yang madani.

Kompleksitas implikasi arus globalisasi tidak dapat dibendung dalam kehidupan masyarakat kini. Menjadi beririsan positif negatifnya teknologi informasi dalam kehidupan masyarakat. Tak dapat dipungkiri, bahwa adanya teknologi dapat memberikan kemudahan, kenyamanan, dan keamanan, tetapi disisi lain, dampak negatif yang ditimbulkan juga begitu besar, bahkan dapat menjadikan budaya instan, mencipta individualitas dalam sosial kemasyarakatan, bahkan dapat memudarkan budayabudaya kebaikan menjadi pembiasaan yang dibawa oleh budaya global melalui berbagai instrumen yang berdampak buruk pada sikap, sifat, maupun perilakunya.

Untuk keluar dari krisis, tidak hanya melakukan transformasi insttitusional, tetapi juga membutuhkan transformasi spiritual yang menekankan pada kehidupan etis penuh welas asih. Serta menekankan pada prinsip moralitas pada jantung kehidupan keagamaan kepada halayak masyarakat luas. (Latif, 2014: 117).

Revitalisasi struktur masyarakat menjadi sebuah alternatif untuk membendung derasnya glolbalisasi yang semakin tak terkendali. Melalui komunikasi, menggeliatkan budaya silaturrahim terhadap ulama atau kiai yang menjadi panutan sebagai bentuk dari patronisasi serta mengembalikan kehidupan sosialnya dalam pusaran budaya andeb ashor. Tentunya ini harus dimulai dari lingkungan yang paling kecil, yaitu keluarga. Bagaimana mengajarkan kembali budaya andeb ashor dalam kehidupan keluarga untuk kemudian menjadi sebuah perilaku yang dapat diaplikasikan dalam kehdupan sosial kemasyarakatan.

\section{Patronisasi dalam Kubangan Globalisasi}

Kuatnya pergeseran arus globalisasi memberikan implikasi yang signifikan terhadap struktur sosial masyarakat Madura. Pergeseran paradigma atau cara pandang tentang kekinian dan modernisasi dalam berbagai aspek, cara berpakaian dan pola hidup yang semakin terbuka serta berbagai aspek perilaku yang mempengaruhi kehidupan sosial masyarakat madura juga ikut bergeser.

Fenomena modernisasi menjadi hal yang lumrah saat ini. Tingkat perilaku yang seringkali mengabaikan prinsip-prinsip andeb ashor dalam kehidupan sosial dan struktur sosial, terutama pada generasi mudanya menjadi tantangan yang harus segera diatasi dari berbagai level sosial kehidupan.

Hal ini dapat merusak tatanan yang sudah lama bersinergi bagi masyarakat madura dalam budaya andeb ashor. Budaya andeb ashor adalah kebiasaan yang dilakukan oleh orang madura dalam menghormati orang yang lebih tua dan menghargai orang yang lebih muda dalam kehidupan sosial kemasyarakatan. Perilaku andeb ashor sudah terkenal sejak ratusan tahun lamanya bagi masyarakat Madura.

Selain ini, masyarkat madura juga terkenal dengan masyarakat santri yang menjunjung tinggi nilai-nilai penghormatan dan penghargaan kepada siapapun dalam kehidupannya. Penanaman budaya tersebut tidak terlepas dari kehidupan keluarga yang diaktualisasikan dalam kehidupan sosialnya.

Chalik (2011), menegaskan bahwa pemimpin keagamaan di Madura itu hanya ada 2 (tiga) kelompok: santri, kyai dan haji. Santri itu adalah murid yang sedang menuntut 
ilmu di pesantren. Kyai adalah guru agama yang dijadikan sebagai patron dalam sebuah desa atau kampung yang menguasai ilmu agama dan menjadi panutan masyarakat desa serta fatwa-fatwanya diikuti disertai perilakunya menjadi panutan dan contoh dalam kehidupan masyarakat Madura. Sementara haji adalah orang yang sudah menjalankan ibadah haji. Sementara itu, Kuntowijoyo, disebutkan oleh Chalid mengemukakan bahwa kyai Madura dikatakan sebagai elit desa yang mempunyai pengaruh signifikan dalam aspek pendidikan, nilai religuitas dan aspek moralitas.

Patronisasi atau meyakini bahwa keberadaan ulama atau orang yang berpengaruh dalam kehidupan masyarakat madura adalah hal yang konkret. Jika tidak mau ikut ulama mau ikut siapa? Bahasa itu yang selalu ditanamkan dalam keluarga. Patron memang menjadi lumrah bagi masyarakat madura. Apa yang didawuhkan oleh ulama pasti diikuti, karena diyakini dan dianggap benar segala perilaku dan ucapannya.

Patronisasi menjadi populer dalam kehidupan masyarakat madura sebagai bagian dari penguatan tatanan kehidupan sosial yang lebih teratur dan dinamis. Para patron biasanya memang mempunyai kemampuan dan kebijaksanaan dalam pola kehidupannya. Menjadi panutan bagi masyarakat, menjadi teladan dalam kehidupan sosial, dan petunjuknya mengarah kepada kebaikan dan kebenaran sesuai dengan ajaran agamanya.

Kentalnya budaya patronisasi ditunjukkan dengan kuatnya perilaku masyarakat madura dalam kehidupannya, hal itu juga bahwa menjadi pola penguatan bagi karakter masyarakat madura yang menjunjung tinggi nilai-nilai andeb ashor, terutama kepada orang yang dipatronkan, sehingga membentuk perilaku, sikap, etika atau moral yang menjunjung nilai-nilai budi luhur yang paling tinggi dalam kehidupan sosial masyarakat madura.

Perlu melakukan pemataan kembali untuk menjaga dan mentradisikan kembali nilai-nilai luhur masyarakat madura yang sudah melekat dalam jiwa dan perilaku masyarakat madura. Patronisasi adalah beririsan dengan budaya andeb ashor yang sudah lama dijadikan sebagai budaya masyarakat madura. Menjadikan ulama atau kiai sebagai panutan dalam kehidupan beragama, bermasyarakat, berbangsa dan bernegara.

Sami'na wa atho'nanya masyarakat madura sungguh sangat luar biasa dalam kehidupan sosialnya. Menjadikan seluruh ucapan dan perilaku seorang patron adalah sebuah keniscayaan yang patut untuk diteladani dan diikuti. Puluhan tahun masyarakat madura menjadikan patronisasi adalah sebuah kewajiban yang tidak dapat dibantah atau didiskusikan.

Namun dekimian, arus globalisasi menjadikan perubahan yang signifikan terhadap masyarakat madura saat ini. Industrialisme "memporak porandakan" arus budaya yang sudah melekat dalam diri masyarakat madura. Perubahan struktur sosial kemasyarakatan juga sudah mulai terkikis rapuh dengan sebab semakin tingginya gerusan arus globalisasi yang melilitkan sikap hedonisme dan kapitalisme dalam kubangan kehidupan masyarakat.

Menangkal dan meredam budaya yang tidak baik dengan tidak menghilangkan kebutuhan masyarakat masa kini adalah dengan mengembalikan dan menjadikan patronisasi sebagai wujud persatuan dan penguatan kapasitas kemasyarakat melalui budaya patron. Apa yang dilakukan oleh kiai atau ulama, itulah yang menjadi panutan bagi masyarakat madura. Kiai dan ulama dijadikan sebagai kekuatan dalam kehidupan masyarakat. Mempercayai dan meyakini bahwa apa yang diucapkan, dilakukan, dan moralitasnya menjadi jujugan dan panutan. 


\section{KESIMPULAN}

Menakar eksistensi budaya andeb ashor dan patronisasi dalam membangun struktur sosial masyarakat madura menjadi penting untuk direvitalisasi. Sebagai masyarakat yang menghargai dan mencintai ulama dan kiai karena penguatan budaya islam yang sudah sekian lama menjadi pedoman hidup masyarakat madura.

Mengembalikan budaya yang semakin surut adalah kewajiban bersama. Saling topang dan berbagi peran tanpa komando adalah sebuah keharusan bagi setiap masyarakat madura. Dimulai dari diri sendiri, dari hal yang paling kecil, dan dari sekarang adalah sebuah kaidah yang menjadi prioritas dalam kehidupan sosial kini.

Melakukan penguatan-penguatan terhadap budaya andeb ashor dan patronisasi melalui berbagai sektor kehidupan masyarakat segera digalakkan. Menyemarakkan musholla dan tempat-tempat tholabul ilmi harus terus dilakukan. Meramaikan pengajian diberbagai agenda masyarakat juga perlu ditingkatkan. Budaya mengaji setelah magrib hingga menjelang isyak. Sekolah-sekolah ibtidaiyah maupun diniyah menjadi tempaan pembelajaran dan pembudayaan andeb ashor dan penguatan terhadap patornisasinya menjadikan masyarakat madura yang lebih baik, berkembang, maju dan sejahtera.

\section{DAFTAR RUJUKAN}

Latif, Yudi. 2016. Yang Laju dan Yang Layu: Membumikan Agama dalam Krisis Ruang Publik. Bandung: Simbiosa Rekatama Media.

Wiyata, A. Latief. 2016. Manusia Madura: Pandangan Hidup, Perilaku, dan Etos Kerja. http://www.lontarmadura.com/manusia-madura-pandangan-hidup-perilaku-etoskerja/. Diakses tanggal 30 Desember 2016.

Chalik, Abdul. 2011. Kiai dan Kekuasaan Sosial dalam Masyarakat Madura. http://www.lontarmadura.com/kiai-dan-kekuasaan-sosial-dalam-masyarakatmadura/. Diakses tanggal 5 Januari 2016.

Latif, Yudi. 2014. Mata Air Keteladanan: Pancasila dalam Perbuatan. Bandung: Mizan. 